This item was submitted to Loughborough's Research Repository by the author.

Items in Figshare are protected by copyright, with all rights reserved, unless otherwise indicated.

\title{
Scouting for girls? Gender and the Scout Movement in Britain
}

PLEASE CITE THE PUBLISHED VERSION

http://dx.doi.org/10.1080/0966369X.2011.583342

PUBLISHER

(C) Taylor \& Francis (Routledge)

VERSION

AM (Accepted Manuscript)

LICENCE

CC BY-NC-ND 4.0

REPOSITORY RECORD

Mills, Sarah. 2019. "Scouting for Girls? Gender and the Scout Movement in Britain". figshare.

https://hdl.handle.net/2134/12147. 
This item was submitted to Loughborough's Institutional Repository (https://dspace.lboro.ac.uk/) by the author and is made available under the following Creative Commons Licence conditions.

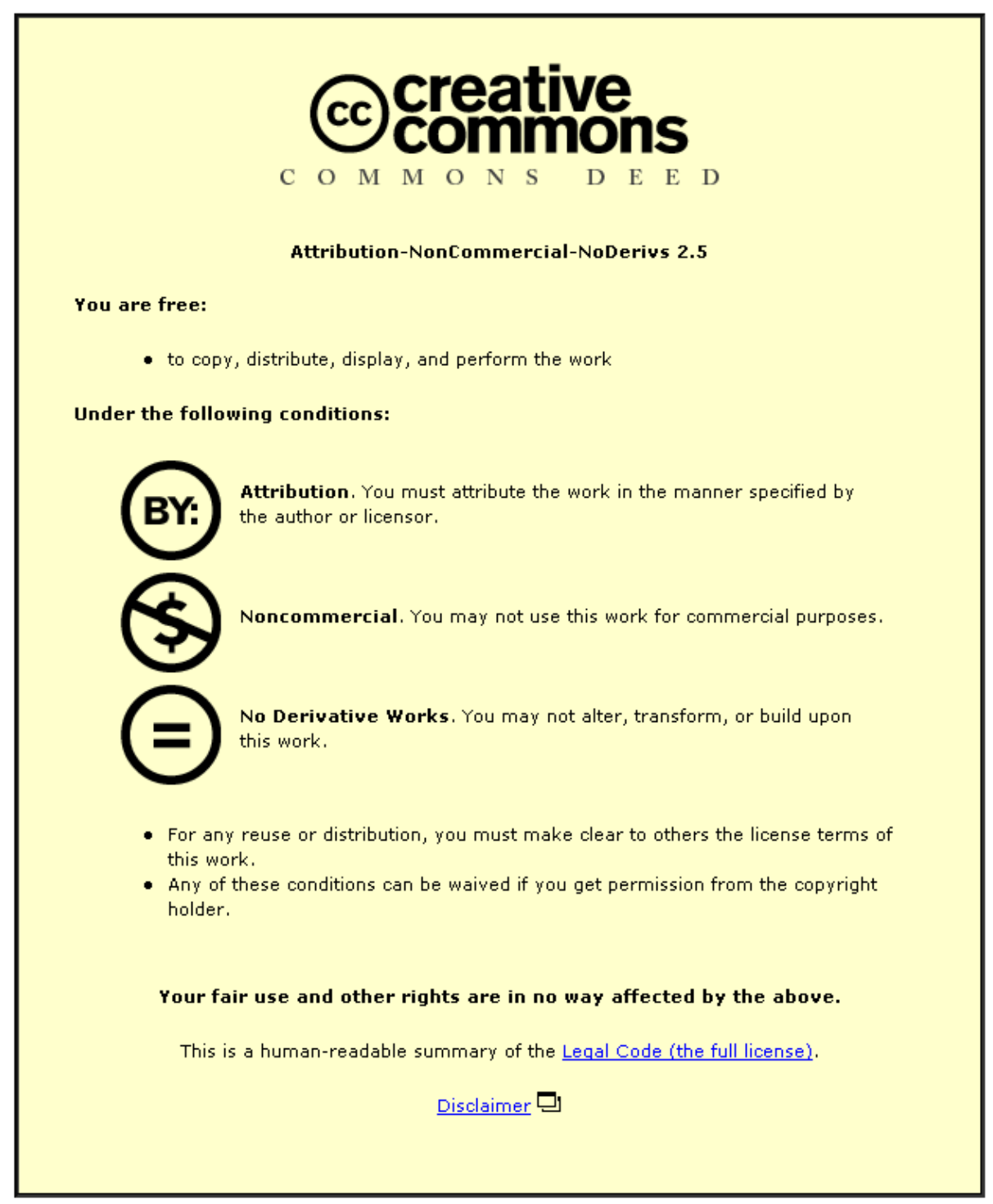

For the full text of this licence, please go to: http://creativecommons.org/licenses/by-nc-nd/2.5/ 


\title{
Scouting for Girls? Gender and the Scout Movement in Britain
}

\author{
Sarah Mills
}

To cite this paper:

Mills, S. (2011) Scouting for Girls? Gender and the Scout Movement in Britain, Gender, Place and Culture: A Journal of Feminist Geography 18 (4): 537-556.

This paper brings a feminist geopolitics to bear upon an analysis of the Boy Scout Movement in Britain in order to illustrate how an emphasis upon seemingly banal, embodied practices such as dressing, writing and crafting can provide a counter-view to prevailing notions of the elite, organisational 'scripting' of individualised, geopolitical identities. Here, these practices undertaken by girls are understood not as subversive, or even transgressive, in the face of broader-scale constructions of the self and the collective body, but rather as related moments in the emergence of a complex, tension-ridden 'movement' that exceed specific attempts at fixity along the lines of gender. Using archival data, I examine various embodied practices by 'girl scouts' that were made possible by such attempts at fixity but which also, in turn, opened up new spaces of engagement and negotiation. A cumulative shift from a determinedly masculine to a co-educational organisation over the course of the twentieth century thus reflects complex geographies of gender, national identity and citizenship and offers a historical contribution to the feminist geopolitics literature.

Key words: youth; feminist geopolitics; embodiment; Scout Movement; Girl Guides

\section{Introduction}

Feminist geopolitics is concerned first and foremost with understanding, and often bringing to light, the embodied, everyday, informal practices that enroll gender into all manner of political landscapes, as well as the diversity of attitudes, emotions and behaviours that make up the 'political.' In the process, this body of work has often drawn attention to the tendency 
within critical geopolitics analyses to eschew such thematics (Dowler and Sharp, 2001; Hyndman, 2001, 2004, 2007). As Jennifer Hyndman states, feminist geopolitics can be viewed as ‘extending' the “work of arguably disembodied critical geopolitical analysis by (re)situating knowledge production as a partial view from somewhere” (2004:309). A key line of inquiry here has been to examine how, using the body as an entry point, 'the state' as an object of analysis can be reconfigured so as to emphasise the manner in which seemingly banal practices, such as dressing, eating, playing and so on, have a profound geopolitical resonance, positioning individuals as gendered, sexualised 'subjects' of both domestic and foreign relations (Secor, 2001; Cope, 2004; Meyar, 2004). Importantly, this sensitivity to issues of embodiment has not affirmed a 'top-down' view of the subject as produced via state-led policies, but, rather, has challenged such a scalar epistemology.

My own research draws upon this reconfiguration of the geopolitical subject and applies it to an analysis of the Scout Movement, the largest youth organisation in the world. Founded in Britain in 1908 as a means of educating boys as to the correct manner of being a citizen, the Scout Movement now has over two hundred national organisations, each of whom hold various rules on who can or cannot be a scout. Rather than assume the organisation as a coherent container within which individuals play out (geopolitical) identities, or as a hegemonic entity that produces resistance, I use a feminist geopolitical approach to unpack the movement as a shifting ensemble of people, objects and knowledges that work to produce particular subjectivities around gender and citizenship, as well as other markers such as member and student. In this paper, I use historical material to explore the actions of British girl scouts at specific points during the last century.

A separate sister organisation for girls - The Girl Guides - was established in 1910, expanding globally from its domestic British foundations. Since 1990, however, there has been a dual system of Scouting for boys and girls in the United Kingdom alongside a still 
thriving Guiding community that remains single-sex. Britain's Scouting structure is the result of a long process of renegotiation lasting several decades and is unique in respect to its mixed sex policy, as attempts at co-educational Scouting have been less successful and rejected outright in other countries (see Miller, 2009; Rothschild, 1982; Varpalotai, 1994; Wittemans, 2009).

In this paper, I uncover the hidden stories of girl scouts in Britain who were "just girls wanting to do the same as the boys" ${ }^{1}$, but who, in doing so, shaped the organisations we know today as the Scout Association and Girlguiding UK. These stories of girl scouts from before 1916 are relatively well known in popular and academic histories (for example, Kerr, 1932; Proctor, 2009). In contrast, the stories of girls who wanted to be scouts in the latter half of the twentieth century, particularly in the 1970s and 1980s, have been hidden within the representations and institutional narratives of the Scout Association itself. Significantly, official narratives present the organisation as the impetus for the move to co-education, rather than girls themselves. In counterpoint, I use my analysis to highlight how some of the everyday struggles of girls and young women to make sense of, and negotiate, their geopolitical existence became focused upon scouting membership, such that repeated efforts were made to articulate some form of belonging. This paper thus focuses on two time periods - 1908-1916 and 1975-1990 - because, whilst there are sixty years between them, they are both significant as moments of activity that resulted in a change to the rules of membership. ${ }^{2}$

These efforts can not simply be read off as 'subversive,' or even 'transgressive,' in the face of broader-scale constructions of the self and the collective body; rather, they emerge as related moments in the continual becoming of a complex, tension-ridden 'movement' that exceed specific attempts at fixity along the lines of gender. In this historical analysis, then, I want to emphasise three key points: firstly, that a focus on embodiment necessitates an evaluation of everyday, mundane and often banal encounters; secondly, that these more 
everyday practises can acquire a momentum that leads to changes in 'movements', reiterating and supporting certain ideals, while negotiating and countering others; and finally, that a methodological approach to uncovering the embodied character of such encounters is not restricted to contemporaneous observation, but can be applied to archival sources.

This article is structured in four sections. In the first, I introduce the feminist geopolitics literature and position this study within its emerging scholarship. The second section provides an outline of the Scout Movement and its youth citizenship project. I then examine how girl scouts made claims to belong to the movement through public and private embodied acts, firstly, during the immediate period after the creation of Boy Scouting and the subsequent creation of Girl Guiding (1908-1916) and secondly, the period between 19751990, in order to discuss the Scout Association's co-educational policies in the latter half of the twentieth century. In examining these two periods, I reflect on the changing relationship between gender and the Scout Movement in the context of a shifting geopolitical project for British youth, before offering some concluding remarks.

\section{Feminist Geopolitics: Enquiries and Possibilities}

As an engagement between feminist theory, political geography and critical geopolitics, feminist geopolitics not only focuses on the gendered discourses of more traditional topics of politics, violence, protest, mobility and security, but also on new research areas such as public and private spaces of geopolitics and post-human landscapes (Dowler and Sharp, 2001; Hyndman, 2001, 2007; Secor, 2001; Sundberg and Kaserman, 2007). How, then, can a feminist geopolitics be brought to bear upon an analysis of an organisation such as the Scout Movement? What analytic purchase does feminist geopolitics provide when considering a voluntary organisation in civil society designed for young people? 
First, the example of the Scout Movement in this paper will demonstrate how national (and in this case imperial) geopolitical attitudes are articulated and (re)produced through a series of processes within the organisation - assemblages of people, practises and objects. These are subsequently embodied in the teachings and practises of the movement and are manifest in the education and play of scouts, who are themselves meant to inculcate a sense of members’ geopolitical identities (on these themes, see Phillips, 1997; Ploszajska, 1996). The Scout Movement has thus become a recognised and romanticised institution - it is regarded as 'part of the British way of life' and is synonymous with a wider imperial British project.

Second, this example of an institutional space, and its associated cultural and historical artefacts, can also be seen as building on the work of 'popular' feminist geopolitics on spaces and various media through which geopolitical imaginations are represented, (re)produced and negotiated. Two examples of popular contemporary mediums that have been analysed within critical (feminist) geopolitics are Joanne Sharp’s (1998, 2000) study of The Reader's Digest and its representation of popular geopolitical imaginations, particularly of the Cold War, and Juliet Fall's (2006) use of the comic books La Frontiere Invisible to exemplify her argument on embodiment, spatiality and critical geopolitics. I would argue that institutions and their meanings and practises can be considered as part of this more expansive and everyday series of encounters with the geopolitical.

Third, this paper therefore draws attention to organisations and incorporates what has been termed 'institutional geographies' (Philo and Parr, 2000) as part of a wider 'institutional turn’ (Jessop, 2001) into feminist geopolitics. The relationship between gender and organisations has been explored in economic geography (McDowell, 2001), development studies (Sweetman, 1997) as well as within the discipline of organisation studies (Acker, 1990; Halford and Leonard, 2001), but here I am concerned with institutional geographies 
and the (gendered) geopolitical visions that youth organisations in particular have constructed in and through space. Institutions are specifically designed to construct both an individualised self and collective body, and additionally in the case of youth organisations, future adult selves. They are places where young members negotiate ideas about belonging and identity, as well as both state and alternative forms of citizenship. As citizens-in-themaking, youth often have their future (citizen) selves scripted and envisioned by adults and spatialised in various formal and informal educational and institutional settings (Gagen, 2000; Weller, 2007) as part of a moral landscape of childhood (Ploszajska, 1994; Valentine, 1996). Scouting and Guiding, as citizenship training schemes devised in early twentieth-century Britain, were attempts to construct fixed gender identities through an institutional setting. These were positioned within a broader geopolitical vision for British youth that determined that the physical and moral fortitude of young people was central to the maintenance of the British Empire.

\section{Methodology: Embodiment and Peformativity from the Archive}

The fieldwork on which this article is based was carried out at the Scout Association archive at Gilwell Park in Essex, England and the archival collection at Girlguiding UK in Central London. I draw on Lorimer's (2003) approach of ‘telling small stories' and his use of various archival and oral history sources to give a narrative focus. The section on early girl Scouting (1908-1916) draws largely on a series of oral histories conducted by the Girl Guide Association in the late 1970s and 1980s. It is worth reflecting critically on these, as the period and events they recall occurred several decades prior to the interviews (on oral histories, see Riley and Harvey, 2007). The importance of these women’s actions when they were young girls might have, in part, been reinforced by official Girl Guide texts and mythology during this period. One could even suggest that these oral histories were in part 
influenced by the moves within the Scout Association towards co-education at the time of their recording. Despite these concerns, these oral histories provide a unique insight into the actions and practises of the first girl scouts in Britain.

Other archival sources, particularly photographic and visual material, have also been analysed in this paper to illustrate the embodied practises of girl scouts. Embodiment involves a consideration of the role that the body plays in our experiences and how bodily practises shape particular events and occurrences (Longhurst, 1997; G Rose, 1993; Radcliffe, 1999). How accounts of embodiment can be garnered from historical data is a methodological challenge for researchers seeking to 'bring to life' the actions, mobilities and practises of individuals encountered in the archive (Gagen et al, 2007; Griffin and Evans, 2008; Lorimer and Whatmore, 2009). The problem with historical research is that “performances and practises are themselves marked by a constitutive absence...we must, by necessity, forgo any claims to the possibility of recovering in fullness the realm of lived gesture, touch and emotion” (Gagen et al, 2007:5).

My own work seeks to re-animate (if only in part) the everyday embodied practises of girl scouts through letters and photographic material which, I would contend, retains traces of the gestural, affective and emotional and communicates historical 'performance', whether it is through the self-styled uniforms of girl scouts, an appropriated Boy Scout enrolment card, or letters written to the organisation. I draw here on the techniques developed by Lorimer and Whatmore (2009:675-6) to examine the material traces and artefacts of girl scouts such as, for example, being affected by the touch and texture of uniforms and badges. Combining this material with oral history accounts allows for a sensitivity to 'more-thanrepresentational' properties of archival material, such as the vibrancy of children's play and adventures as girl scouts as told through childhood memories. 


\section{Constructing the Scouting Citizen: Scouting for Boys}

On returning from the Boer War (1899-1902), Robert Baden-Powell devised an informal citizenship training scheme for British boys - Scouting - and tested his ideas at an experimental camp in 1907. Its aim was to teach self-discipline, self-improvement and resourcefulness through a number of activities including woodcraft and camping. 'Natural' and rural landscapes were used as arenas for citizenship training (Matless, 1995; Cupers, 2008) in line with several other youth movements that emerged in Britain at the beginning of the twentieth century (Wilkinson, 1969; Springhall, 1977). Practises of Scouting were very much inspired by existing ideas that connected nationhood with nature, fitness and bodily strength (Gagen 2004); indeed the motivation for Scouting was largely due to the fears over the future of the British nation and empire left in the hands of a 'lazy' and 'unhealthy' next generation of boys and men (MacDonald, 1993). The military persona of Baden-Powell and the fears his scheme tapped into about the physical and mental strength of British (male) youth at that time is a clear example of how national and imperial geopolitical visions comeinto-being and are spatialised through schemes such as the Scout Movement.

Most historical studies of the Scout Movement have centred on its imperial ambitions and Edwardian discourses of militarism, morality and masculinity (Warren, 1987; Dedman, 1993; Rosenthal, 1986). Its development abroad has also lent itself to academic attention in studies on gender, race and religion (MacLeod, 1983; Mechling, 2001; Parsons, 2004; Watt, 1999). Similarly, the history of the Girl Guides has been studied through social histories (Kerr, 1932) and academic work on its ideological assumptions and development across the globe (Warren, 1990; Miller, 2007; Proctor, 2009) as well as the differences between Scouting and Guiding (Proctor, 1998, 2002; Wittemans, 2009).

In 1908, Baden-Powell published his ideas in a fortnightly magazine Scouting for Boys which was the catalyst for the movement's unprecedented domestic and international 
growth (Boehmer, 2004). In this text, Baden-Powell outlined his citizenship model that would encourage boys to develop both as a young citizen and for their future adult self. His model was based on three underlying principles - Duty to Self, Duty to Others and Duty to God - all of which are included in the Scout Promise and reflected in the Scout Law, a code of living or moral geography that encourages good citizenly-like behaviours. Scout behaviour was positioned along the lines of 'good' or 'bad' to create a moral landscape of youth citizenship and an 'ideal' Scouting citizen to emulate; in many ways parallels can be drawn here with the construction of an 'ideal childhood' nurtured through various institutions (Gagen, 2000; Kraftl, 2006). This ideal Scouting citizen would be patriotic, strong (physically and mentally), loyal, honest, trustworthy, competent in outdoor knowledge and useful to the community.

The 'model' Scouting citizen was also distinctly male. Many of the roots of the movement are founded in a 'hard-bodied masculine ideal' and Baden-Powell sought to create a space for men and boys of different backgrounds to build a male community tied up with ideas of patriotism, patriarchy and empire. The emergence of Scouting, though occurring at a time of growth in the women's rights and women's suffrage movements, still remained firmly based on the fixed gendered ideologies that characterised early twentieth century Britain (Pugh, 1992; Ramelson, 1967). The composition of the ideal Boy Scout raises a series of philosophical and geographical questions about notions of the self and other (N Rose, 1996) with Scouting ‘others’ including troublesome ‘deviant' youths in Britain, non-Britons abroad and female youth, against which the individual Scouting self was constructed. As well as fostering the development of an individualised self, Scouting also highlighted at the same time an individual's position as part of the wider collective of scouts on the national and global scale. These beliefs then filtered down through the organisation and became embodied in various teachings and practises. The everyday practises of scouts - woodcraft, camping, 
knot-tying - were not just seen as pastimes with the reward of badges, but rather were viewed by adults as training in good citizenship and crucial to creating a moral landscape of British youth (Matless, 1995, 1997). There is therefore an inherent geopolitics of Scouting: adults teaching young people their expected roles at local, national and international scales as well as ensuring their competence and proficiency in skills deemed useful to the nation, and ultimately the empire.

This ideal Scouting citizen can be, and has been, negotiated during its history through social and cultural difference, and most powerfully I would argue, through gender. Indeed, other 'challenges' to its membership criteria by young people subscribing to Communist or non-Christian religious communities have been less visible, resulting in less prominent and more occasional disputes and exclusions. Though the movement was designed exclusively for boys who set up Scout Troops across Britain, Baden-Powell's scheme also appealed to young girls who began to adopt the title 'scout'.

\section{"Please Sir, we're the Girl scouts": Girl Scouting and the creation of The Girl Guides (1908-1916)}

Many individuals have claimed to be the first 'girl scout', or have been dubbed so in the press. However, the reality is that there were hundreds of girls who began Scouting in Britain during 1908. In many cases, girls acquired or borrowed a copy of Scouting for Boys from male relatives and were enthralled by the promises of adventure and fun it contained. Girl scouts organised themselves into small troops of female family members and friends or joined with boys to create mixed troops, as did Marguerite du Beaumont from Norfolk:

We simply dressed ourselves, turned our stockings down on our knees, collected all the broomsticks we could find in the broom cupboard and went to Scout HQ and bought scout hats, which in those days you could do. They didn't ask us who we were or anything about it. It was a mixed patrol, we had two little boys, I think four little girls... and we used to do Scouting. ${ }^{3}$ 
Acquiring scout hats, adjusting stockings and appropriating broomsticks were the beginnings of self-styled scout uniforms for girls, which in other accounts included scout shirts handsewn by girls themselves. Miss Elsie Lee, described as 'the first girl scout in NewcastleUpon-Tyne', is photographed here in her 'hotchpotch' uniform:

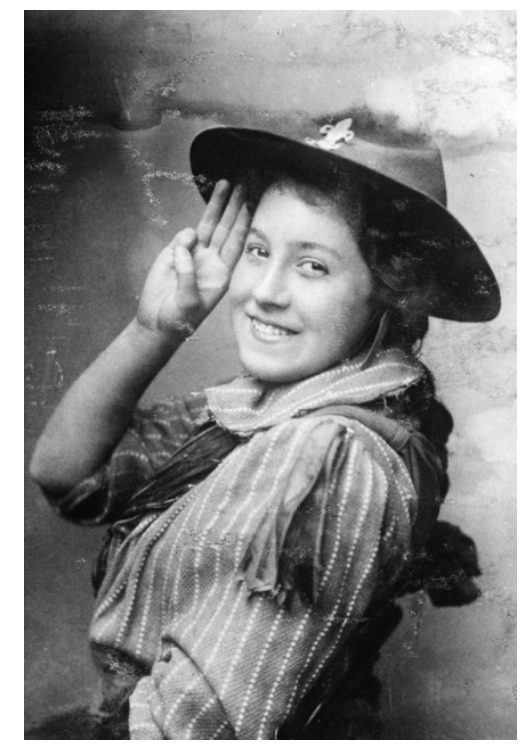

Figure 1. Miss Elsie Lee, the first girl scout in Newcastle upon Tyne (1908) (By kind permission of GirlGuiding UK, GH1908/2).

Elsie is photographed wearing a patterned blouse rather than official khaki scout shirt and a fashioned scarf or necktie in place of an authorised Group neckerchief. She is, however, modelling an official scout hat adorned with the insignia of a fleur-de-lis and making the scout sign with the right hand as outlined in Scouting for Boys. This combination of official parts of the 'culture' of Scouting, crossed with homemade uniform alternatives to appear in the likeness of a scout, demonstrates the difficulties of how a founding organisation could control the users and interpretations of its ideas once these were placed in the public sphere.

Girl scouts such as Elsie went largely unnoticed during the organisation's formative months, particularly as scouting was a largely grassroots development with groups of young people forming troops in towns and villages without central co-ordination. In other cases, local Scoutmasters representing the national Scout authorities 'on the ground' accepted direct 
requests from girls, such as Sybil Cannadine from London, to be scouts. Sybil and her friends approached the Scoutmaster at St. Mark’s Camberwell who "saw no reason why not, but couldn't give us any help, except the book”. ${ }^{4}$ Sybil's troop had no adult supervision, and while this suggests that girls achieved a degree of self-reliance more quickly than their male counterparts, in its early years Scouting was characterised by wildly differing experiences and levels of supervision. Sybil and her fellow girl scouts at St. Marks became engaged in the same activities as boy scouts:

On Saturday afternoons at a discreet distance, we used to follow the boys to Peckham Rye. There, with Scouting for Boys in our hands, we learned how to track, and stalk, how to cook our very modest tea, how with our poles, broomsticks really, we were able to jump the fences and the little streams. ${ }^{5}$

Girl scouts, wherever they were meeting, and whoever they were meeting with, were in essence performing the same practises and activities as the boy scouts. To imagine from these accounts the adventures these girl scouts had on Saturdays, and to hear the excitement and child-like passion in Sybil's now elderly voice, is to gain a sense of how inspiring the original messages of Scouting would have been. In participating in the same adventurous activities designed for male youth, I would argue that these original girl scouts were also engaging with powerful ideas about the nation and empire - ideas not intended for them. These girls had begun, at an informal independent level, to negotiate the meanings about who could be a scout and the overarching constructions of both a (masculine) Scouting self and wider collective body of boy scouts. However, they could only do this to a certain extent as they were not allowed to participate in authorised Scouting spaces.

The official message from Headquarters on the issue of girl scouts was somewhat misleading. A report from a Scout Competition in Wimbledon in May 1908 stated that "we were very glad to see...several girl scouts wearing their badges”. ${ }^{6}$ Baden-Powell himself professed that girls could be worthy and useful scouts and that "I am always glad to hear of 
girls’ patrols being formed"; he even went as far to say that "there is no reason at all why girls should not study scoutcraft”. ${ }^{7}$ Conversely, parents and politicians found plenty of reasons why girls should not study scoutcraft, based largely on Edwardian views about gender and the troubling rise of tomboys (Dyhouse, 1981). The presence of girl scouts threatened the respectability and undermined the moral (single-sex) purpose of this new organisation inspired by a number of gender and race-related anxieties (MacDonald, 1993). The public criticism Baden-Powell received for seemingly allowing girl scouts meant this issue needed to be resolved quickly. As the months went by, Headquarters started to regulate the spaces of Scouting with registration procedures, and yet girl scouts somehow circumvented these new elements of control. When denied official access, many applied to become members anyway and access materials through the post using only their initials, or through their brothers' names. This allowed girl scouts to go relatively unnoticed by disguising their real identity and evading the attention of authorities. One example where a specific object bears witness to such past practises can be seen in Figure 2:

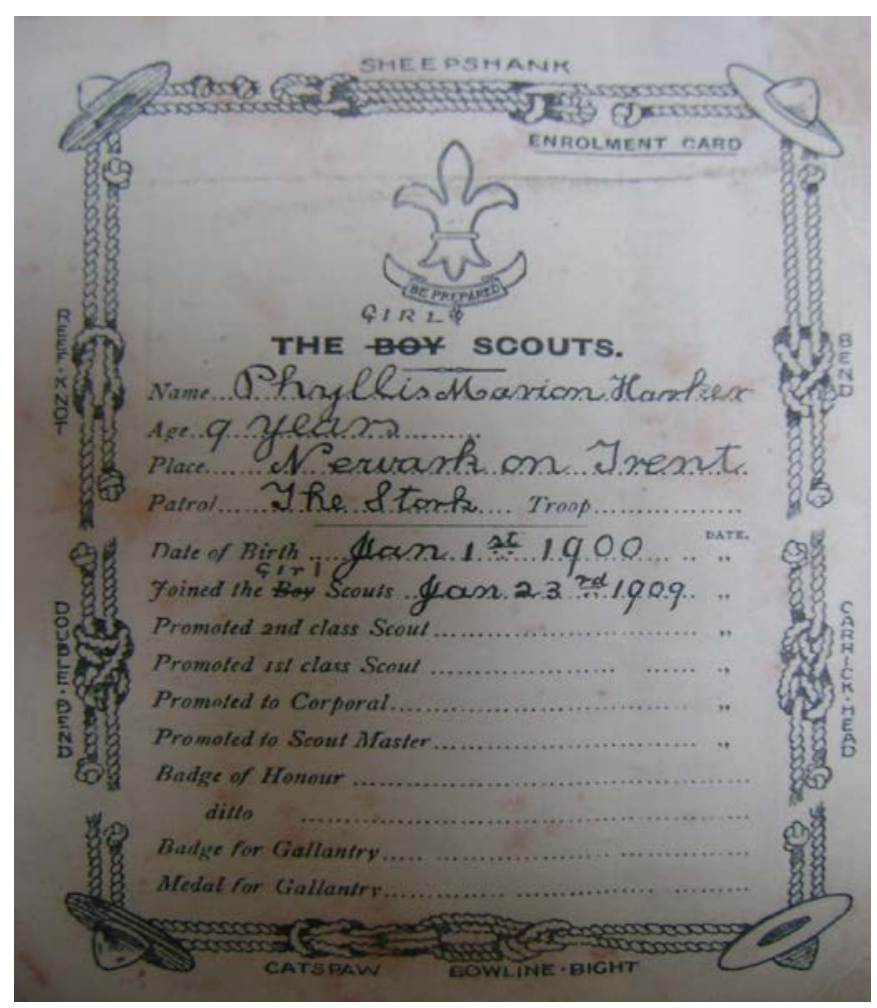


Figure 2. Enrolment card (1909). (By kind permission of Girlguiding UK, Early Girl Scouts Folder)

This official Boy Scout enrolment card had either been ordered by, or come into the possession of, nine year old Phyllis Hasker who then crossed out the printed word 'Boy' that precedes 'Scout' and replaced it with 'Girl' on two occasions. Furthermore, instead of this card being completed by a Scoutmaster, Phyllis has consciously decided to record her own progress as an independent scout, though it is noted no further achievements are recorded. This not only highlights how individual girls bypassed the machinery of Scouting as an organisation, but also the ways in which young people practised Scouting away from the authoritative gaze of adults associated with youth work and educational spaces. The card, emblazoned with official scout insignia and illustrations of knots and scout hats, is a personal artefact that tells of the individual appeal to Scouting and the creativity of naming one's patrol (in this case, 'Stork'). The seemingly banal act of crossing out a word and making this into a girl scout card can be seen as an act of appropriation as well as demonstrative of the sense of belonging that the movement inspired - to boys and girls. It also highlights that whilst there was a different and self-styled form of Scouting for girls, individuals such as Phyllis still utilised the official materials produced by the organisation. These types of objects, despite being appropriated by girl scouts, ultimately supported and reiterated Scouting ideals and (gendered) geopolitical identities.

Girl scouts would soon open up new spaces of engagement and negotiation in the public sphere through their desire to access the same spaces as boys and fully participate in the activities and ethos of being a Scouting citizen. By 1909, over 6000 girls had registered with headquarters as scouts and in September of that year, the first ever Boy Scout Rally was held at Crystal Palace in London (Scout Association, 2006:48). The rally was attended by 
over 10,000 boys as well as an unexpected small number of girl scouts who 'gatecrashed' dressed in their homemade and borrowed uniforms. Figure 3 shows girl scouts at the review standing amongst boy scouts, to whom the King sent a message urging them "to do their duty as men should any danger threaten the empire.”

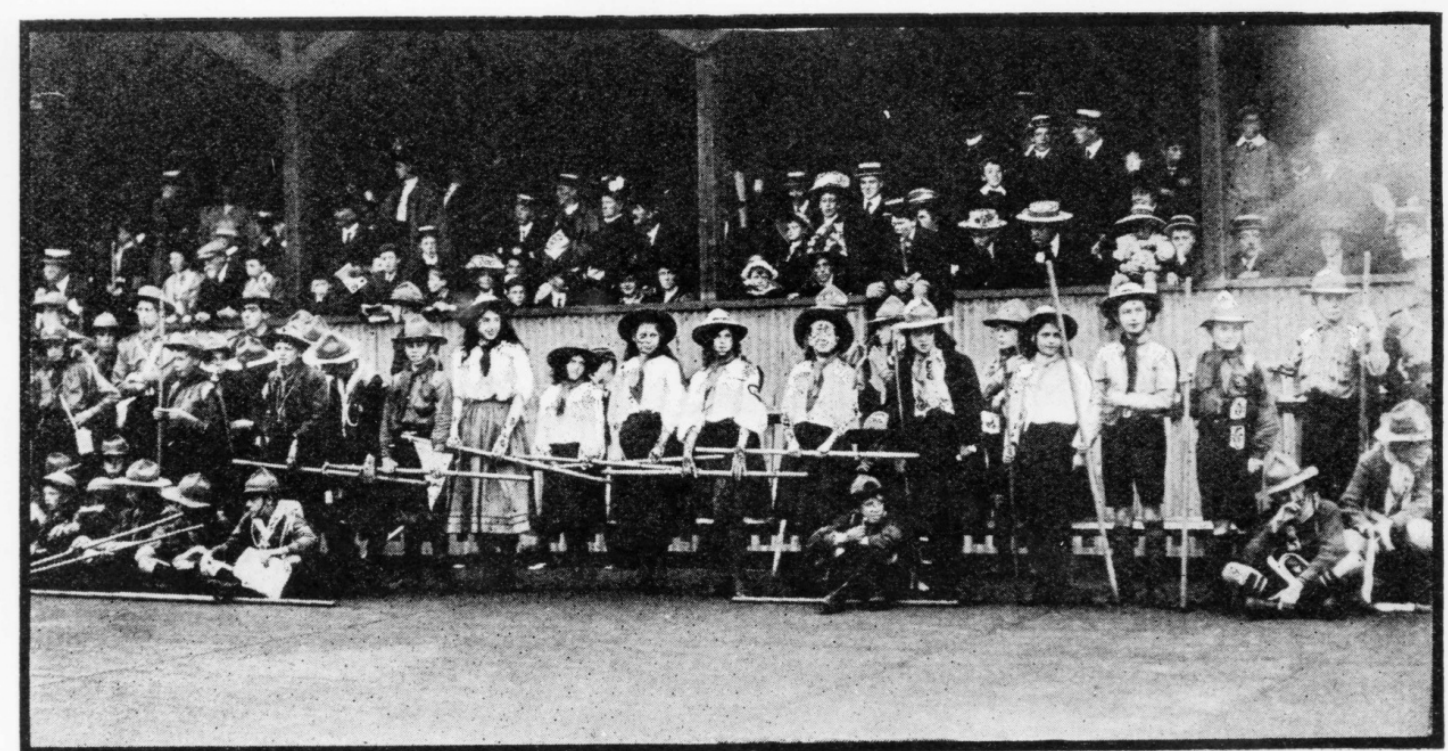

SOME OF THE GIRL SCOUTS AT THE CRYSTAL PALACE LAST SATURDAY

The Scout idea has spread to girls, of whom forty (mostly from Shoreditch and Reigate) were present at the great review at the Crystal Palace last Saturdiy. The King sent a message to the Boy Scouts: "Please assure the boys that the King takes the greatest interest in them, and tell them that if he shotild call upon them later in life, the sense of patriotic responsibility and habits of discipline which they are now acquiring as boys will enable them to do their duty as men should any danger threaten the Empire."

Figure 3: Boy Scout Rally at Crystal Palace, $4^{\text {th }}$ September 1909.

(By kind permission of Girlguiding UK, Early Girl Scouts Folder)

Accounts vary about the response the girls received. Whilst Sybil describes that "we were laughed at, we were whistled at, there were cat-calls, but we didn't mind - we were there and we were part of the show"8, Marguerite recalls that "nobody took the slightest bit of notice of us”. 9 On arrival, for many girl scouts, it was a shock to see boys:

It was a Scout rally and, of course, having called ourselves scouts, we thought all scouts were girls and boys - mixed. But then we discovered they weren't - they were all boys...And then B.P himself came up to us and said 'what are you doing here? Who are you?' We said 'Please Sir, we're the girl scouts' and he said 'I've never heard of you. Anyway, you better come and join in' which of course pleased us very much. ${ }^{10}$ 
As Proctor (2002:21) notes, in official Guiding and Scouting mythology, this Rally is often cited as the 'first time' Baden-Powell realised he needed to create a separate organisation for girls and yet my previous discussion highlights that Baden-Powell had heard and written about girl scouts prior to the Rally.

Indeed, as I reflected earlier with regards to the oral histories, the story of Crystal Palace is somewhat embellished as a defining moment, yet I would argue that the girl scouts - and their disruptive and out-of-place bodies - did become visible and, significantly, they were inspected as scouts. Again, we can see how ideals encouraged through Scouting, such as uniformed self-discipline, were supported by girl scouts. However, through parading and dressing as girl scouts as well as participating in the competitions at the Rally, these girls were challenging who could claim to be a 'scout', rejecting the fixed gendered identities Scouting was built upon, and demanding access to the official institutional spaces of Scouting.

After Crystal Palace, public opinion on the girl scouts reached a crescendo. A debate running over a number of weeks in The Spectator in December 1909 stemmed from an original protest letter from Miss Violet Markham about girl scouts being out late at night and "ranging the country with a pole". ${ }^{11}$ Editorial and public opinion was divided, from those who felt “it is better that a girl should become a 'tomboy' than an idle doll with poor morals" 12 to the condemnation that "is it not an anxious sign of the times if the mothers of girls...have not sufficient control to prevent their daughters from taking part in a pursuit of which they disapprove, especially one so eminently unsuitable as Scouting for girls?”. ${ }^{13}$ This debate was ended by the Managing Secretary of the Boy Scouts, J. Archibald Lyle, who wrote to The Spectator stating that "there appears to be an impression that Girl Scouts form part of the organisation of Boy Scouts. This is not so" ${ }^{14}$ He also announced that a new scheme for girls was in the pipeline. 
This new separate girls’ organisation - The Girl Guides - would be a 'sister' organisation to Scouting and is often described as a natural outcome or branch of the movement (on the early development of Guiding, see Warren, 1990; Jeal, 1991:469-487). The Girl Guides were named after a famous corps of soldiers known as the Guides on the Northwest Frontier of India, as well as literally 'guides' who lead the way across hazardous terrains. There are further gendered implications of the title 'Guide' in terms of duty and helping others, and whilst these are also important themes in Scouting, the term 'scout' suggests (masculine) performances of exploration and adventure.

In a similar guise to Scouting, Girl Guiding developed a programme that fostered the notion of developing the individual self, as a young Guiding citizen, whilst simultaneously highlighting through the culture of Guiding an individual's role as part of the wider collective of Guides throughout the nation and the world. The new scheme of Girl Guides again had fixed gender roles in mind and aimed to teach girls feminine virtues, as boys were taught masculine ones, thus distancing themselves from the 'tomboy' character. In the words of Agnes Baden-Powell, Robert's elder sister and the figurehead of early Guiding until 1918 when his wife, Olave, became Chief Guide:

This organisation, although on parallel lines with that of the Boy Scouts, is different in its aims and details. Whereas the teaching of the Boy Scouts develops manliness, that of Girl Guides makes for womanliness, in both cases by means which appeal to the young people themselves. ${ }^{15}$

This womanliness was encouraged for a specific purpose - to create a parallel stream of young citizens - still with imperial ambitions but with a different role to play in this vision. The ideal Guiding citizen and their citizenship training focused on a Girl Guide’s future role as a woman, wife and mother to create a future womanhood fit to support and help the men of the nation.

Guides were taught that their roles in the home would be their contribution as active, useful citizens. In light of this aim, Girl Guide activities included learning how to lay a table 
and laundry skills to accompany traditional Scouting activities of camping, knot-tying and nature study; new proficiency badges such as cook (1910), florist (1910) and needlewoman (1912) clearly reflect the gendered and domesticated skill-set Guiding authorities imagined for its female membership. These different practises, though seemingly everyday and mundane, were significant as part of a broader geopolitical project in British society at that time in outlining the different roles of women and men as imperial subjects working as part of a cohesive collective national body.

Indeed, there is a strong link here between domesticity and empire and the significance of the home in the subtle construction of an empire 'at' home (Blunt, 1999). For scouts and guides, the repetition of these (gendered) skills, the focus on continued improvement and the challenge of proficiency were part of a socialisation process and a reinforcement of the different sets of knowledge that girls and boys were seen to need in adulthood. Though the badges were an outward sign of proficiency emblazoned on uniforms, it was the skills learnt from adult instruction and their usefulness to others that were seen as the higher aim for female youth.

In replying to a written request to wear scout badges from a Miss Biddy Stuart Deacon, a girl scout still practising Scouting in her mixed troop 'The Red Cliff Scouts' in Cheshire as late as 1916, Baden-Powell refused permission, encouraged her to join the Girl Guides and assured her "there is always the satisfaction of knowing that you have passed the necessary tests for them which is far more important than the actual badges”. ${ }^{16}$ Indeed, Biddy and others like her demonstrated that enthusiasm for the new scheme was not universal. As Marguerite recollects, "When we became Girl Guides, it became a bit of a bore, because they were all so respectable, we didn't have any fun”. ${ }^{17}$ Key elements of Scouting culture had been altered for Girl Guides: a new navy blue uniform replaced scout khaki and the animal names of scout patrols gave way to plant and flower motifs. Dame 
Anstice Gibbs and Mrs Wade, two early Girl Guiders and influential members of Girl

Guiding recall:

When they started of course they wanted to be scouts, and they were scouts and they called themselves scouts. They adopted the scout mottos and they had the patrol names, the animals, the wolves, the bears and so on and they didn't appreciate it at all when the rather Victorian Headquarters of that time put their foot down and suggested that they should be roses and lilies and violets instead. ${ }^{18}$

While most girl scouts did eventually join the new scheme, they tried to retain some autonomy and identity as 'girl scouts' within their newly prescribed organisation. Some continued to wear their home-made scout khaki uniforms for months and years afterwards, resisting the change to navy blue and compromising on the removal of their animal patrol names with bird names, rather than the suggestions of flowers and plants. These small acts, particularly the continued practise of making and sewing their own(scout) uniforms and insignia, can be seen as a process of identification as scouts. These were embodied practices that visibly challenged the image of an ideal 'guide' to the organisation and wider public. As individual girls were told that they were 'guides' rather than 'scouts', some began to resist the changes and the imposition of these new identities. Significantly, these girls were questioning the roles laid out for them in the foundation texts of Guiding, particularly the suggestion that women could be useful citizens only in their capacity as mothers and wives. Instead these girls continued to subscribe to those original scout ideals that had meant so much to them.

\section{The continued ‘problem’ of Girl Scouts: 1975-1990}

In the period 1975-1990 there was a 'second-wave' of challenges by girls who wanted to be scouts. Again, we can see the way in which the embodied practises of writing and dressing were used by girl scouts to challenge their subscribed gendered geopolitical identities. 
Though there is a definite clustering of 'activity' regarding girl scouts in both the early twentieth century and again from the 1970s onwards, a minority of girls remained a constant (yet well hidden) feature of Scouting during the intervening sixty year period. However, headquarters was more concerned with the dramatic loss of (male) adult leaders following the two World Wars and in developing Scouting abroad. This intervening period also saw widespread changes in Guiding as it became a well-established and popular youth organisation. British society underwent enormous social and political changes with increasing levels of women in paid employment, increasing political participation and the emergence of youth as a social and political category (Fowler, 2008; Marwick, 1970).

In 1975, fourteen-year old Susan Shield joined the $64^{\text {th }}$ Newcastle Scout Group as their first 'girl scout'. Susan's Scoutmaster cited her persistence as the reason to let her join. Susan wore an official scout shirt (though a male design) that was widely available from local Scout shops, unlike in the first decades of Scouting. The case of Susan as an individual selflabelled 'girl scout', photographed in uniform and making the Scout Promise, contests the popular public image and original normative construction of who a scout should be. This somewhat mundane and seemingly trivial story of a girl scout in Northern England quickly came to be conflated with issues around the place of women per se in British society, as Susan was asked about equal pay and stated in the press “I agree with Women’s Lib...I think they should have equal money if they do the same job”. ${ }^{19}$ Susan's views on equal pay and her support for women’s liberation were clearly influenced by second wave feminism, and yet, she had rejected the all-female space of Guiding and its rhetoric of female independence. Her desire to 'Scout' was articulated instead in terms of gender equality and for British youth to be able to participate in all informal spaces of youth organisations.

The official Headquarters response to these one-off instances (once they had found out) was that girls could categorically not be scouts and they must leave and become guides. 
These and other similar stories of girl scouts did, however, open up new negotiations and discussions about Scouting's continued fixity along gender lines. In 1976, the National Scout Board requested reports from Scout Groups on the situation regarding any girls in their troops. These asked questions such as "What are your present numbers of boys and girls?, “how do you integrate the girls?” and “what do you do about uniform?”. ${ }^{20}$ One could argue that it appears the organisation was playing catch-up to the negotiations going on at a local level outside of their immediate control. Later on that year, the Scout Association, in its own words, “opened its doors” to girls aged 15 - 20 in the oldest of its sections - Venture Scouts. Older girls were now being incorporated as Scouting (rather than Guiding) citizens. This official inclusion of girl scouts resulted in some practical modifications to Scouting, for example, the introduction of a different uniform and alterations in programme material. Significantly, this move re-framed (older) female members as compatible with the broader citizenship project of Scouting for British youth.

Once older girl scouts had been allowed, younger girls saw an opportunity and pressed harder to become scouts, as oppose to guides, through letters to the Headquarters such as this one from 1978:

To National Scout Council,

The Girls of Clover Hill are trying to get a Girl Scout troop started. We are NOT interested in Guides, but are very interested in being Scouts. We know several Girl Scout Troops exist around the country which are illegal. PLEASE please please could we be the first legal troop? ${ }^{21}$

Another letter from 1986, by which point there was still no progress on the issue of younger girls in Scouting, is shown in Figure 4: 


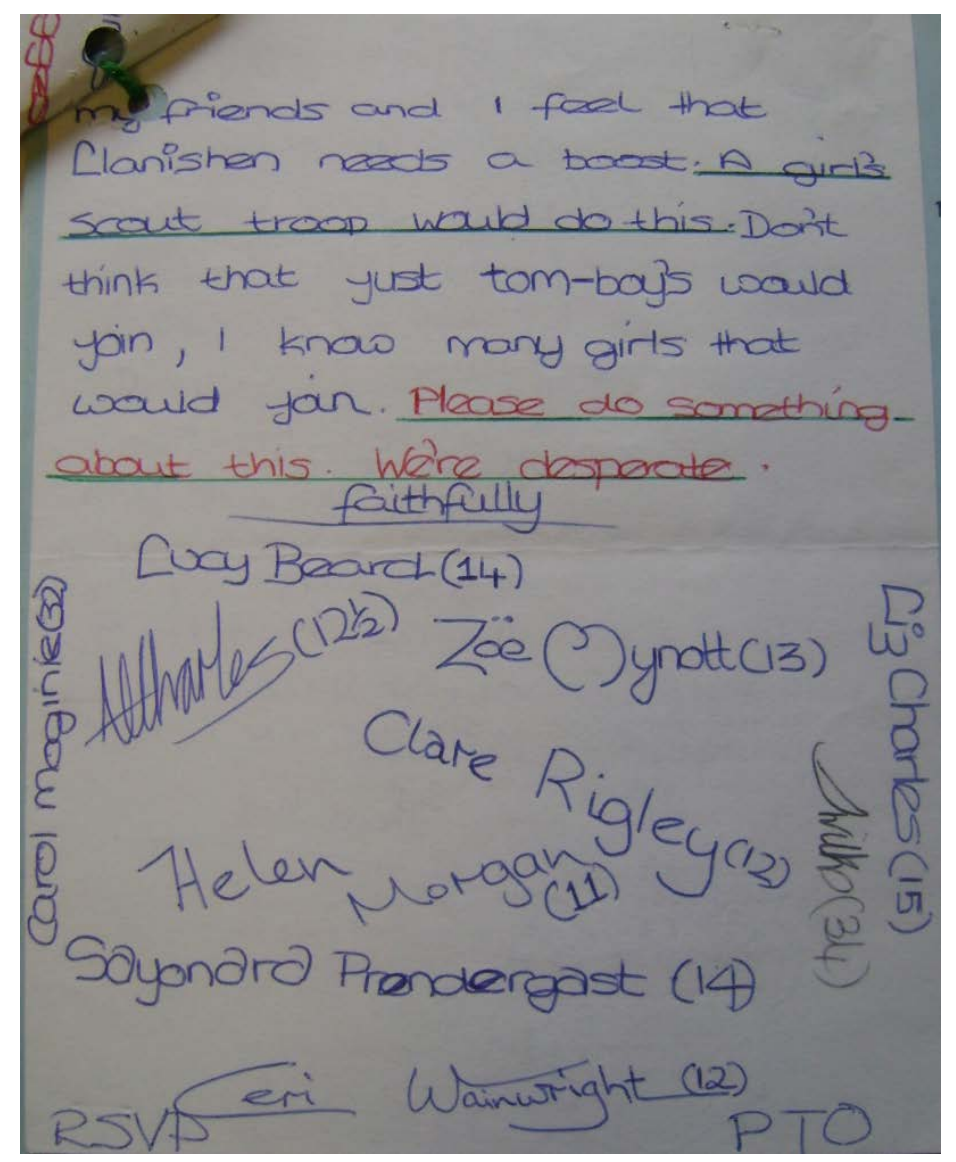

Figure 4. Letter from Llanishen girls, 1986. (By kind permission of the Trustees of The Scout Association, TC/310).

These handwritten letters addressed to the Scout Association, signed by young girls, identified the organisation's concerns and pleaded to be included in the movement. More and more leaders threatened to 'go public' about girls they had allowed to join their Groups and this meant the Scout Association was forced to consider girl scouts once more. A working party was set-up in the late 1980s to discuss the possibility of extending provision for girls. Following their discussions, there occurred a radical shift in policy in February 1990 when Scout Groups across the UK could decide to 'opt-in’ to mixed-sex Scouting and allowed girls as young as six, such as those in Figure 5. Here, two girls - a Scout and a Cub Scout - are 
pictured in a traditionally masculine environment of a tool shed, dressed in full official uniform and adorned with outdoor equipment:

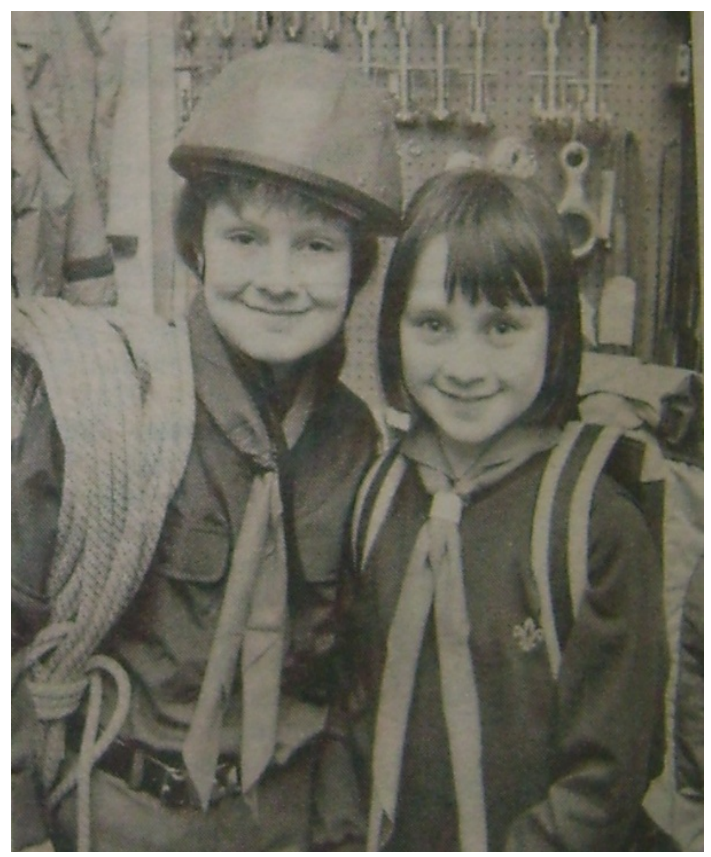

Figure 5: 'Call of the Scouts', Staffordshire Newsletter, 18 February 1990, p. 5 (By kind permission of Staffordshire Newsletter.)

This policy announcement was the first time that girl scouts of all ages had been officially allowed in UK Scouting. The move again involved a re-negotiation of 'Scouting' identity and a number of practical changes. Guidelines were drawn up over 'mixed-camp etiquette', a new uniform was introduced (Figure 5) and separate requirements for badges such as the Athlete's badge were drawn up for boy and girl scouts. Though framed in terms of gender equality, these changes were predicated on earlier concerns raised about girl scouts: fears over boys and girls mixing in the countryside, uniform, and their physical ability to complete adventurous Scouting activities. Indeed, whilst looking like a transformation, the organisation was in fact re-framing concerns raised in its formative years.

Though appearing on the organisation's terms, I would argue this move was part of a process of an emerging, ever-changing and complex organisation. This 1990 ruling provided 
an opportunity for the movement to present itself as open and tolerant through an 'invitation' for girls to join. It also stated that "one thing is clear: as of now we have girls knocking on our doors demanding to be allowed to join”. ${ }^{22}$ As my previous examples have shown, girls were knocking on the door long before 1990 and yet the media portrayed these girl scouts as a brand new idea, a novel and comical spin on an age-old British institution and also presented the organisation as the impetus, the driving force for change, rather than as a result of a series of challenges and negotiations.

The decision to include all girls in the framework of UK Scouting created a strong reaction within Scouting and Guiding with most objections stressing this move would dilute the identity of a scout and their image of who or what a scout should look like. The decision also created debate and friction between the Scout and Guide Association who naturally saw female youth in Britain as their target membership. In a press release the Girl Guide Association stated that it "regrets the decision" and "feel the Scout Association's decision is surprising because there is increasing emphasis in the Youth Service on single-sex provision”. ${ }^{23}$ Guiding in the UK continues to be an all female-space and has stressed its desire to remain so in the future; in 2007 its recorded membership of 517, 070 still outweighed that of the Scout Association and their 465,000 young members.

In 2007, the centennial year of Baden-Powell’s experimental scout camp, it became compulsory for all Scout Groups in the UK to accept girls in all sections - making the 1990 voluntary ruling obsolete. It is now, in theory, a fully co-educational space, with a few exemptions based on religious requirements, for example Scout Groups in Mosques (Mills, 2009). There has also been a shift in the geopolitics of Scouting and the construction of fixed gendered identities as young citizens. Whilst Scouting originally focused on ideas of Britishness and empire, it has gradually moved away from the nation-state as the primary focus of its citizenship training. Instead, it has moved towards internationalism and global 
citizenship as a framework for its structural and ideological philosophy. This also has implications for gender - casting women in a new geography of citizenship that considers actions and behaviours. Indeed the aim of the UK Scout Association today, with both male and female members, is "to develop young people as responsible citizens and as members of their local, national and international communities”. ${ }^{24}$

It would appear that those original girl scouts have eventually achieved what they wanted - a space in which to be scouts. Guiding celebrates its centenary in 2010 and began its year of celebrations in September 2009 to mark the anniversary of the Crystal Palace Rally. For one of those original girl scouts, Marguerite, who went on to a successful career in Guiding and Scouting, her feelings on her lifetime status as a scout are clear:

Really at the bottom...there is only one movement...As he [Baden-Powell] had always told us, once a scout, always a scout. Can't get away from it. ${ }^{25}$

\section{Conclusion}

In bringing a feminist geopolitics to bear on the Scout Movement, this paper has examined how the everyday lives and practises of young people can be positioned in relation to more formal and grandiose state geopolitical visions. The fixed gendered geopolitical identities envisioned for boy scouts have, over time, been challenged by the routine, mundane and everyday practises of girl scouts. Embodied practises of wearing modified uniforms, crafting and writing were used by early girl scouts to circumvent the mechanistic governance of the organisation. These methods of subterfuge were employed by girl scouts to identify with Scouting ideals, participate in Scouting activities and spaces, and counter the gendered geopolitical identities associated with Scouting.

Girl scouts engaged in transgressive embodied practices, but they were still supporting and attracted to the original ideals of Scouting. Their presence in the masculine landscapes of Scouting, such as the Crystal Palace Rally, also demonstrates how girl scouts 
supported its ideals of uniformed discipline, self-sacrifice and patriotic duty. However, the decision by the girls to attend the Rally without tickets or invitations, and their encounter with Baden-Powell, shows how they began to counter the fixed gendered geopolitical identities that were designed for boy scouts. This highlights the reflective nature of Scouting and its appropriation by individuals over time, amidst a broader geopolitical vision for British youth.

The subsequent creation of the Girl Guides cemented these 'fixed' geopolitical identities for male and female youth, through the parallel structures of Scouting and Guiding. The routine and mundane familiarity of Scouting and Guiding calendars and programmes were, in essence, training in the citizenship models laid out for British youth bythe BadenPowells. As this paper has shown, many girls continued to profess a desire to be scouts. In this instance, the embodied practises of dressing, crafting and writing were used as smallscale acts of resistance to remain as scouts whilst attending Girl Guides. Similarly, the moves in the 1970s and 1990s towards co-education were influenced, in part, by the presence and letters of self-styled uniformed girl scouts. These somewhat banal and embodied practises, brought about by attempts at fixity along the lines of gender, became effective sources and sites for resistance to the original masculine ideal of a Scouting citizen. These actions by girl scouts were not subversive, but rather can be seen as moments in the emergence of a complex movement through a re-envisioning of Scouting's citizenship model. In reflecting on the practises of girl scouts, the time-specific context is also important to consider, as wanting to be a scout would have meant something different at varying points in the twentieth century. The question of motivation here is central - What was it about being a 'scout' that appealed to some girls more than being a 'guide'? Whilst there was clearly a unique element in the early years of Scouting in terms of its activities, I would suggest that there was something about the freedoms, both perceived and actual, that came 
with being a 'scout' that remained appealing to girls. Furthermore, the accounts of girls who desperately wanted to be scouts demonstrates how powerful the idea of Scouting was, and remains. There was an intrinsic appeal to the identities and ideals that Scouting encouraged. Indeed, even though many of the girl scouts were protesting against those fixed gendered identities, there was still a strong desire to be included in its citizenship project as 'scouts'.

The example of girl scouts and the embodied practises through which they negotiated change have not only shown how embodiment is accomplished in practise, but also provide a counterview to prevailing notions of elite organisational 'scripting' of individualised geopolitical identities. This focus on embodiment highlights the everyday, mundane and often banal encounters which I have argued have momentum in changing the nature of 'movements' in so far as reiterating and supporting certain ideals, but in negotiating and countering others. Furthermore, a methodological argument has been made that evidence for embodied performativity can be garnered from historical data and archival sources. This paper has shown how an analysis of an everyday space using feminist geopolitics can benefit from a historical perspective in order to examine changes in how individuals negotiate their geopolitical existence over time and space. In exploring the actions of girl scouts at specific points during the last century, it is clear that the everyday struggles of young women to make sense of, and negotiate, their geopolitical existence is nothing new.

\section{Acknowledgments}

Thanks are extended to the Economic and Social Research Council (Grant no. ES/F00737X/1) and the archival staff at the Scout Association and Girlguiding UK. This paper has benefited from thecomments of three anonymous reviewers in addition to those of Rhys Jones, Rhys Dafydd Jones, Peter Merriman and the editorial guidance of Deborah Dixon. 


\footnotetext{
${ }^{1}$ Sybil Cannadine, 1977, oral history recording, GirlGuiding UK Archive (hereafter GGUK), CD Ten, Track One.

${ }^{2}$ This is not to say, however, that girls who preferred to be scouts rather than guides have not featured throughout the course of the organisation's history.

${ }^{3}$ Marguerite de Beaumont, 1978, oral history recording, GGUK, CD Nine, Track One.

${ }^{4}$ Sybil Cannadine, 1977, oral history recording, GGUK, CD Ten, Track One.

${ }^{5}$ Sybil Cannadine (unknown date) The Guide Movement, recorded monologue, GGUK, CD Ten, Track Two.

${ }^{6}$ Robert Baden-Powell. 1908. The Scouts' Competition in Wimbledon. The Scout 30 May, p.162.

${ }^{7}$ Robert Baden-Powell. 1908. Girl Scouts Again! The Scout 12 September , p.506

${ }^{8}$ Sybil Cannadine, 1977, oral history recording, GGUK, CD Ten, Track One.

${ }^{9}$ Marguerite de Beaumont, 1978, oral history recording, GGUK, CD Nine, Track One.

${ }^{10}$ Marguerite de Beaumont, 1978, oral history recording, GGUK, CD Nine, Track One.

${ }^{11}$ Violet Markham to the Editor, 'Girl Scouts' The Spectator, 4 December 1909, p.942

12 'Death-Knell of the "Girl Scout”' to the Editor, 'Girl Scouts' The Spectator, 11 December 1909, p.994

${ }^{13}$ A.K. to the Editor, 'Girl Scouts', The Spectator, 18 December, 1909, p.1051

${ }^{14}$ J. Archibald Lyle, Managing Secretary of the Boy Scouts to the Editor, 'Girl Scouts', The Spectator, 25

December 1909, p.1100

${ }^{15}$ Baden-Powell, Agnes (1910) Girl Guides: Note Scout Association Archive (hereafter SAA) /TC/351A

${ }^{16}$ Correspondence between Robert Baden-Powell and Miss Biddy Stuart Deacon, 5 February 1916, Early Girl Scouts Folder, GGUK.

${ }^{17}$ Marguerite de Beaumont, 1978, oral history recording, GGUK, CD Nine, Track One.

${ }^{18}$ Dame Anstice Gibbs and Mrs Wade, 1988, oral history, GGUK, CD Eleven, Track One.

${ }^{19}$ Scott, Barbara (1975) 'Scouting history: And now Susan’s just one of the boys' The Journal 1 December 1975

20 'Girls in Scouting', Report, SAA/TC/310.

${ }^{21}$ Correspondence from thirteen girls at Clover Hill, Norwich, England, received 1 September 1978, SAA/ TC/310.

${ }^{22}$ Internal Scout Association Memorandum, 13 February 1990, SAA/ TC/310.

${ }^{23}$ Girl Guides Association Response to Statement made by Scout Association on 8 February 1990, P.1-2, SAA/ TC/310.

${ }^{24}$ Scout Association. 2009. Mission Statement http://scouts.org.uk/cms.php?pageid=131

${ }^{25}$ Marguerite de Beaumont, oral history, 1978, GGUK, CD Nine, Track One.
}

\section{References}

Acker, Joan. 1990. Hierarchies, jobs, bodies: a theory of gendered organizations. Gender and Society 4, no.2: 139-158.

Blunt, Alison. 1999. Imperial Geographies of Home: British Domesticity in India, 18861925. Transactions of the Institute of British Geographers NS, 24, no.4: 421-440.

Boehmer, Elleke. 2004. Introduction and Notes on Scouting for Boys. In Scouting for Boys [1908] Baden-Powell, Robert. Oxford: Oxford University Press.

Cope, Meghan. 2004. Placing Gendered Political Acts. In Mapping women, making politics: Feminist Perspectives on Political Geography, ed. L. A. Staeheli, E. Kofman, and L.J.Peake., 71-86. New York: Routledge.

Cupers, Kenny. 2008. Governing through nature: camps and youth movements in interwar Germany and the United States. Cultural Geographies 15, no.2: 173-205.

Dedman, Martin. 1993. Baden-Powell, Militarism, and the 'Invisible Contributors' to the Boy Scout Scheme, 1904-1920. Twentieth Century British History 4, no.3: 201-223. 
Dowler, Lorraine, and Joanne Sharp. 2001. A feminist geopolitics? Space and Polity 5, no. 3:165-176.

Dyhouse, Carol. 1981. Girls Growing Up in Late Victorian and Edwardian England London: Routledge and Kegan Paul.

Fall, Juliet J. 2006. Embodied geographies, naturalised boundaries, and uncritical geopolitics in La Frontière Invisible. Environment and Planning D: Society and Space 24, no.5: 653669.

Fowler, David. 2008. Youth Culture in Modern Britain c.1920-c.1970: From Ivory Tower to Global Movement: A New History Basingstoke: Palgrave Macmillan.

Gagen, Elizabeth A., Hayden Lorimer and Alex Vasudevan. 2007. Practising the archive: some introductory remarks. In Practising the Archive: Reflections on Method and Practice in Historical Geography, ed. E. Gagen, H. Lorimer and A. Vasudevan, 1-8. Historical Geography Research Series (40), London: Royal Geographical Society/IBG

Gagen, Elizabeth A. 2000. An example to us all: child development and identity construction in early $20^{\text {th }}$-century playgrounds. Environment and Planning A 32, no.4: 599-616.

Gagen, Elizabeth A. 2004. Making America flesh: physicality and nationhood in early twentieth-century physical education reform. Cultural Geographies 11, no.4: 417-42.

Griffin, Carl, and Adrian Evans. 2008. On Historical Geographies of Embodied Practice and Performance. Historical Geography 36: 5-16.

Halford, Susan, and Pauline Leonard. 2001. Gender, Power and Organisations Basingstoke: Palgrave Macmillan.

Hyndman, Jennifer. 2001. Towards a Feminist Geopolitics. Canadian Geographer 45, no.2: 210-222.

Hyndman, Jennifer. 2004. Mind the gap: bridging feminist and political geography through geopolitics. Political Geography 23, no.3: 307-322.

Hyndman, Jennifer. 2007. Feminist geopolitics revisited: body counts in Iraq. The Professional Geographer 59, no.1: 35-46.

Jeal, Tim. 1991. Baden-Powell. London: Pimlico.

Jessop, Bob. 2001. Institutional re(turns) and the strategic-relational approach. Environment and Planning A, 33, no.7: 1213-35.

Kerr, Rose. 1932. The Story of the Girl Guides London: The Girl Guides Association.

Kraftl, Peter. 2006. Building an idea: The material construction of an ideal childhood. Transactions of the Institute of British Geographers 31, no.4: 488-504. 
Longhurst, Robyn. 1997. (Dis)embodied geographies. Progress in Human Geography 21, no.4: 486-501.

Lorimer, Hayden. 2003. Telling small stories: space of knowledge and the practice of geography. Transactions of the Institute of British Geographers 28, no.2: 197-217.

Lorimer, Jamie, and Sarah Whatmore. 2009. After the 'king of beasts': Samuel Baker and the embodied historical geographies of elephant hunting in mid-nineteenth-century Ceylon. Journal of Historical Geography 35, no.4: 668-689.

MacDonald, Robert. H. 1993. Sons of the Empire: The Frontier and the Boy Scout Movement 1890-1918 Toronto: University of Toronto Press.

MacLeod, David. 1983. Building Character in the American Boy: The Boy Scouts, YMCA and their Forerunners, 1870-1920 Madison, WI: University of Wisconsin Press.

Matless, David. 1995. The Art of Right Living: landscape and citizenship, 1918-39. In Mapping the Subject: geographies of cultural transformation, ed. N. Thrift and S. Pile., 93122. London: Routledge.

Matless, David. 1997. Moral Geographies of English Landscape. Landscape Research 22, no.2: 141-155.

Marwick, Arthur. 1970. SocialChange in Britain 1920-1970 London: Birbeck College.

McDowell, Linda. 2001. Linking scales: or how research about gender and organizations raises new issues for economic geography. Journal of Economic Geography 1, no.2: 227-250.

Mechling, Jay. 2001. On My Honor: Boy Scouts and the Making of American Youth Chicago: The University of Chicago Press.

Meyar, Tamar. 2004. Embodied Nationalisms. In Mapping women, making politics: Feminist Perspectives on Political Geography, ed. L. A. Staeheli, E. Kofman, and L.J.Peake, 153-68. New York: Routledge.

Miller, Susan. A. 2007. Growing Girls: The Natural Origins of Girls' Organizations in America New Brunswick: Rutgers University Press.

Miller, Susan. A. 2009. Trademark: Scout. In Scouting Frontiers: Youth and the Scout Movement's First Century, ed. N.R. Block and T.M. Proctor, 28-41. Cambridge: Cambridge Scholars Publishing.

Mills, Sarah. 2009. Citizenship and Faith: Muslim Scout Groups. In Muslim Spaces of Hope: Geographies of Possibility in Britain and the West, ed. R. Phillips, 85-103. London; New York: Zed Books.

Parsons, Timothy H. 2004. Race, Resistance and the Boy Scouts Movement in British Colonial Africa Athens; Ohio: Ohio University Press. 
Phillips, Richard. 1997. Mapping Men and Empire: A Geography of Adventure London: Routledge.

Philo, Chris, and Hester Parr. 2000. Institutional Geographies: Introductory Remarks. Geoforum 31, no.4: 513-521.

Ploszajska, Teresa. 1994. Moral landscapes and manipulated spaces: gender, class and space in Victorian reformatory schools. Journal of Historical Geography 20, no.4:413-429.

Ploszajska, Teresa. 1996. Constructing the subject: geographical models in English schools, 1870-1944. Journal of Historical Geography 22, no.4: 388-398.

Proctor, Tammy M. 1998. (Uni)Forming Youth: Girl Guides and Boy Scouts in Britain, 1908-39. History Workshop Journal 45, spring: 103-134.

Proctor, Tammy M. 2002. On My Honour: Guides and Scouts in Interwar Britain. Philadelphia: American Philosophical Society.

Proctor, Tammy M. 2009. Scouting for Girls: A Century of Girl Guides and Girl Scouts Santa Barbara, CA; Denver, CO; Oxford, England: Praeger

Pugh, Martin. 1992. Women and the Women's Movement in Britain 1914-1959 Basingstoke: Palgrave Macmillan.

Radcliffe, Sarah A. 1999. Embodying national identities: mestizo men and white women in Ecuadorian racial-national imaginaries. Transactions of the Institute of British Geographers 24, no.2: 213-225.

Ramelson, Marian. 1967. The Petticoat Rebellion: A Century of Struggle for Women's Rights London: Lawrence and Wishart.

Riley, Mark, and David Harvey. 2007. Talking geography: on oral history and the practice of geography Social and Cultural Geography 8, no.3: 345-351.

Rose, Gillian. 1993. Feminism and Geography: The Limits of Geographical Knowledge Cambridge: Polity Press.

Rose, Nikolas. 1996. Identity, Genealogy, History. In Questions of Cultural Identity, ed. Hall, S. and du Gay, P., 128-150. London; Thousand Oaks, CA; New Delhi: SAGE.

Rosenthal, Michael. 1986. The Character Factory: Baden-Powell and the Origins of the Boy Scout Movement New York: Pantheon Press.

Rothschild, Mary A. 1981. To Scout or to Guide? The Girl Scout-Boy Scout Controversy, 1912-1941. Frontiers: A Journal of Women Studies 6, no. 3: 115-21.

Scout Association. 2006. An Official History of Scouting London: Hamlyn. 
Secor, Anna J. 2001. Towards a feminist counter-geopolitics: gender, space and Islamist politics in Istanbul. Space and Polity 5, no.3: 191-211.

Sharp, Joanne P. 1998. Reel geographies of the new world order: patriotism, masculinity and geopolitics in post-Cold War American movies. In Rethinking geopolitics, ed. G. Ó Tuathail and S. Dalby, 152-169, London: Routledge.

Sharp, Joanne P. 2000. Condensing the Cold War: Reader's Digest and American Identity. Minneapolis: University of Minnesota Press.

Springhall, John. 1977. Youth, Empire and Society: British Youth Movements 1883-1940 Beckhenham: Croom Helm.

Sundberg, Juanita, and Bonnie Kaserman. 2007. Cactus Carvings and Desert Defecations: Embodying Representations of Border Crossings in Protected Areas on the Mexico-US Border. Environment and Planning D: Society \& Space 25, no.4: 727-744.

Sweetman, Caroline. ed. 1997. Gender in Development Organisations Oxford: Oxfam Professional.

Valentine, Gill. 1996. Angels and devils: moral landscape of childhood. Environment \& Planning D: Society and Space 14, no.5: 581—599.

Varpalotai, Aniko. 1994. Women Only and Proud of It!: The Politicization of the Girl Guides of Canada. Resources for Feminist Research 23, nos.1-2: 14-23.

Warren, Allen. 1987. Popular Manliness: Baden-Powell, Scouting and the development of manlycharacter. In Manliness and Morality, Middle Class Masculinity in Britain and America, 1800-1940, eds. J.A. Mangan and J. Walvin, 199-219, Manchester: Manchester University Press.

Warren, Allen. 1990. Mothers of the Empire? The Girl Guides Association in Britain, 19091939. In Making Imperial Mentalities: Socialisation and British Imperialism, ed. J.A.Mangan, 96-109, Manchester: Manchester University Press.

Watt, Carey A. 1999. The promise of 'character' and the spectre of sedition: The boy scout movement and colonial consternation in India, 1908-1921. South Asia: Journal of South Asian Studies 22, no.2: 37-62.

Weller, Susie. 2007. Teenagers' Citizenship: Experiences and Education London; New York: Routledge.

Wilkinson, Paul. 1969. English Youth Movements, 1908-1930. Journal of Contemporary History 4, no.2: 3-23.

Wittemans, Sophie. 2009. The Double Concept of Subject and Citizen at the Heart of Guiding and Scouting. In Scouting Frontiers: Youth and the Scout Movement's First Century, ed. N.R. Block and T.M. Proctor, 56-71. Cambridge: Cambridge Scholars Publishing. 